\title{
PARITY OF LIVEBORH CHILDREN IN SERBIA: PATTERN BY EDUCATIONAL LEVEL OF WOMEN
}

DOI: http://dx.doi.org/10.18509/GBP.2016.35

UDC: 316.662.2:37-055.2:314-12(497.11)

\author{
M.Sc. Natalija Mirić \\ University of Belgrade Faculty of Geography, Serbia
}

\begin{abstract}
APSTRACT
This paper explores the pattern of parity of liveborn children with respect to the women's educational level. Cohort method of demographic analysis based on data from Census of Population and Households (2011) is used in this research.The analysis includes all women who were above reproductive age and those who aged between 40 and 49 years at the moment of conducting of the Census 2011. The indicators which are used in this analysis are: percent of childless, share of women by order of birth and probabilities of an increasing of family. The educational structure of women includes three modalities: low-educated, secondary-educated and high-educated women. Results show that pattern of parity of liveborn children has differed with regard to the women's educational level.
\end{abstract}

Keywords: fertility, women's educational level, parity of children, Serbia, Census 2011.

\section{INTRODUCTION}

Serbia has faced with the problem of low fertility for longer than half of century. The total fertility rate (TFR) has ranged from 2.12 children per woman during the 60s of XX century to 1.4 children per woman during the $2000 \mathrm{~s}$. According to the latest data, TFR is $30 \%$ below replacement level. Parallel with declining of fertility below replacement level, Serbia has been a witness of changing of socio-economic position of women in the past few decades. The expansion of education has influenced on the transformation of the educational structure of women which can be express by the fact that high-educated women have been the most growing educational category of population. The date of Census 1961 indicated that $1.3 \%$ of women was high-educated, while the lastest Census 2011 showed that 16,3\% of women was high-educated (Graph 1). Therefore, negative association between fertility and education has been evident in Serbia, i.e. an increasing of the share of high-educated women has been accompanied by declining of fertility. Therefore, an expansion of education can be consider as important determinant of insufficient reproduction in Serbia. 
Graph 1: Total fertility rate and share of high-educated women in total female population in Serbia, 1961-2011.

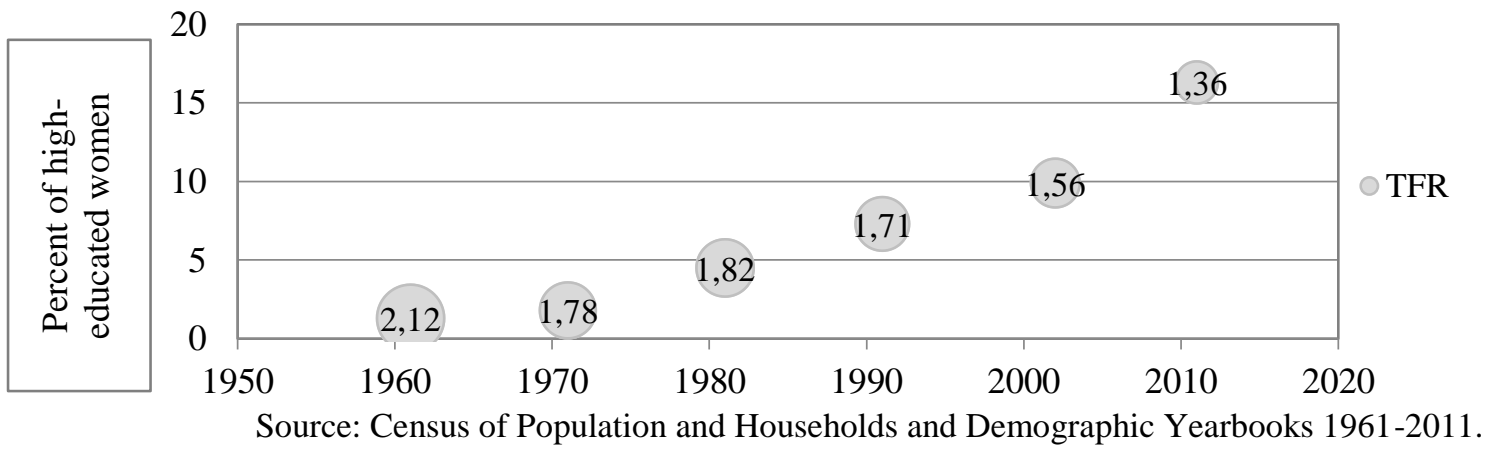

Education as determinant of fertility has been analyzed in more complex studies of empirical nature, either as one of the independent variables [3], [9], [10], [12], or as a segment of population policy towards fertility [5] and a significant factor in reproductive health. The goal of this paper is to point to the parity of liveborn children with regard to women's educational level in Serbia. Determining of differentiation of the reproductive behavior between women of the different levels of education is very important regarding to divergent trends of fertility and female educational structure.

\section{THEORETICAL BACKGROUND}

The link between education and fertility has occupied a very important place in the scientific literature. Kravdala \& Rindfussa (2008) have stated that education and fertility have been two fundamental processes in the social metabolism. In the literature, the increasing of education has been associated with the expansion of post-materialist values and norms that shape the low fertility preferences [8], as well as an increasing of an opportunity costs of childbearnig [1],[2]. Thus, both theoretical approaches, culturally and economically, suggest that an increasing of education has been an important factor of the declining of fertility, i.e. its assume that women's educational level and fertility have negatively correlated.

In the context of the Second Demographic Transition Theory, high-educated women have left traditional norms and they are "less prone" to family life which result in fewer children or childlessness. So, they can be considered as pioneers of socio-economic change which include reproductive behavior. Van de Kaa (2001) has indicated that the „higher-order needs" have been appeared by the expansion of post-materialist values which has reflected in the postponement of family and lower fertility.

It should be noted that motivation for parenthood differentiates depending on the women's education. The survey research, which was conducted at the end XX century in Serbia, has shown the differences in motivation for parenthood between high-educated women and other women [3]. On the one side, less educated women have cited motives of parenthood which are close to the instrumentalization of children, while on the other side, individualistic motives of parenthood that provide better life through leaving of traditional norms, have been typical for high-educated women. Respectively, motherhood is seen as one of the ways of satisfaction of emotional needs among high-educated women.

Economic Theory of fertility connects education and fertility through two mechanisms [2]. First, "income effect" suggests a positive correlation between education and fertility, 
given that high-educated women generally perform more high paying jobs which facilitate the starting and maintenance of family. However, this positive effect can be weakened by investing of income in the quality rather than in the quantity of children. Second mechanism is the "price effect" that points to negative correlation between education and fertility through higher opportunity costs of childbearing among higheducated women. On the one hand, the increasing of women's education affects to their activation on the labor market and higher income, but on the other hand it causes the increasing of costs of time which woman spends on "non-market" activities and costs of children. Thus, the "price effect" implies that the need for children is reduced by increasing of opportunity costs among high-educated women.

\section{METHODOLOGY AND SOURCE OF DATE}

Cohort (longitudinal) method of demographic analysis based on the data from Census of Population and Households 2011 has been used in this research. The completed fertility has been in the focus of this research, therefore the analysis has included women who were above reproductive age (cohort born at 1951 and earlier) and women who aged between 40 and 49 years (cohort born between 1962 and 1971) at the moment of conducting of the Census 2011. The educational structure of women has included three modalities: low-educated, secondary-educated and high-educated women (Appendix). The indicators of parity of live born children that have been used in the analysis are: percent of childless, share of women by order of birth and probabilities of increasing of family (probabilities of increase in the number of children). The calculation of these indicators is based on the Census's question "Number of live born children" which has been an integral part of all post-war censuses in Serbia. The mentioned probabilities have the following meanings: $\mathrm{a} 0$ - the probability of childless women to born at least one child; a1 - the probability of women with one child to born at least two children, etc. The values of probabilities a0, a1, a2 ... a9 are obtained in the following way [4]:

$$
\mathrm{a} 0=\sum_{1}^{9+} \mathrm{V}_{\mathrm{s}, \mathrm{x}} / \sum_{0}^{9+} \mathrm{V}_{\mathrm{s}, \mathrm{x}} \text { etc. }
$$

$\sum_{1}^{9+} \mathrm{V}_{\mathrm{s}, \mathrm{x}}, \sum_{0}^{9+} \mathrm{V}_{\mathrm{s}, \mathrm{x}}$ etc. are cumulants which are calculated based on a distribution of women by number of liveborn children and age: $V_{s, 0}$ - number of women without children; $V_{s, 1}$ - number of women with one child etc. ( $\mathrm{s}$ - symbol to marking the group). The paper has been devided into two segments. The first part indicates to the educational pattern of structure of women by number of liveborn children. The second segment presents the educational pattern of probabilities of increasing of family.

\section{RESULTS}

\section{EDUCATIONAL PATTERN OF STRUCTURE OF WOMEN BY NUMBER OF LIVEBORN CHILDREN}

Distribution of women by number of liveborn children enables analysis of childlessness as one of the direct causes of fertility. The results have shown that childlessness and female education have been positively correlated in Serbia, i.e. permanent childlessness has been characteristic primarily of high-educated women. Almost double higher proportion of high-educated women has been childless in compared to the less educated 
women in all age cohorts. Comparison of age cohorts points to rising trend of permanent childlessness among high-educated women in Serbia. Specifically, every the fourth higheducated woman aged 40-44, and every the fifth high-educated woman aged 45-49, has been childless. In contrast, the percent of childlessness has been fairly stagnant among secondary-educated and low-educated women (Graph 2).

The fact is that the percent of childlessness can be partly explained by a certain level of infertility and possibilities of medicine and pharmacology in the treatment and diagnosis of infertility, as well as the "sensitivity" of women to these achievements. This is particularly important in explaining of differences in childlessness among women above reproductive age with respect to their education. On the one hand, the percent of childless among less educated women has been higher among the oldest in compared to younger cohorts above reproductive age, on the other hand, this difference is negligible among high-educated women. This points to the fact that high-educated women have been "more sensitive" to medical developments which have resulted in the elimination of this factor in the creation of difference in the percent of childless between age cohorts. In general, higher level of childlessness among high-educated women in compared to other women has been expression of factors, both economic and socio-cultural nature, which contribute to self-willed abandonment from the motherhood. Also, it should be noted that the largest share of childlessness among high-educated women aged 40-44 can be explained by the social-economic conditions in the Serbia during the period when this generation was in the optimal reproductive age. This generation of women (and partially generation 45-49) was in the optimal reproductive age at the 90 s of the XX century, i.e. a period which was marked by the destruction of the country, economic collapse and inflation. The difficult social-economic climate in Serbia in this period was reflected in the poor perception of the future. In addition to the factors which through increasing of opportunity costs and post-materialist values have contributed to childlessness among high-educated women, should be considered this "specific factors" which have been important in a deterministic basis of fertility in Serbia.

Graph 2. Percent of childless by women's educational level in Serbia, 2011. (\%)

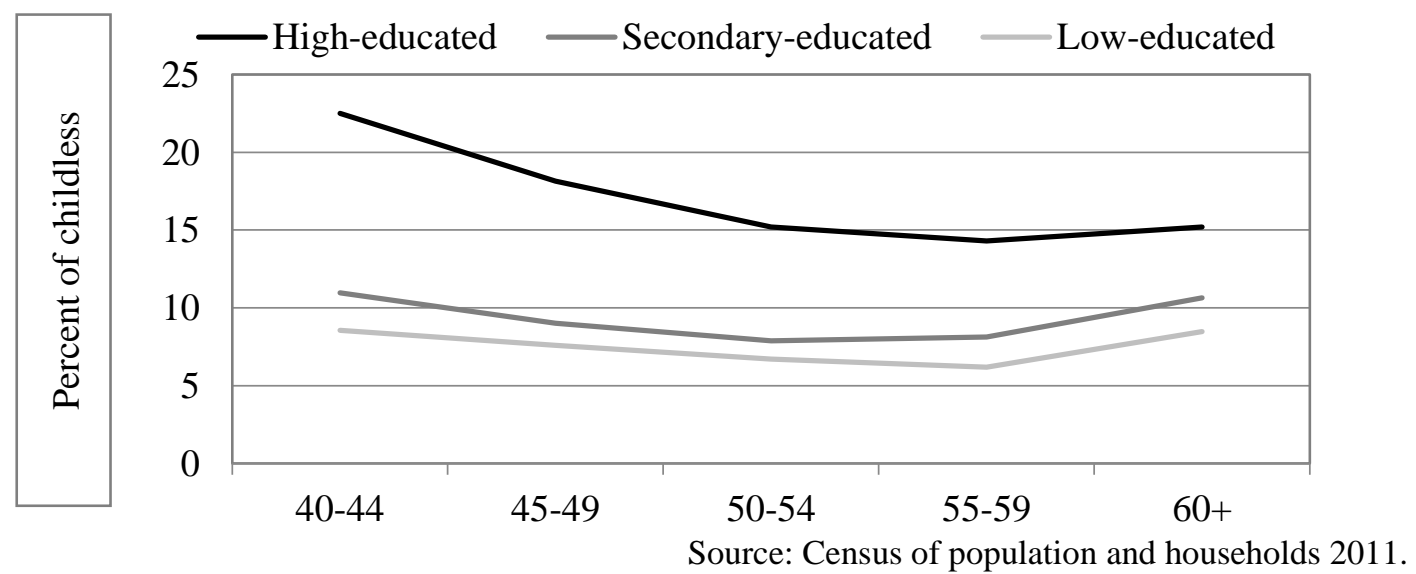

If we observed women who have had child/children, propensity to two-children families has been dominant among women of all levels of education. On average over $60 \%$ of women in Serbia have lived in two-children families, regardless of their education. However, the data have shown that the propensity towards bigger families has been more pronounced among less educated women than high-educated women. The share of low- 
educated women who have given birth to three or more children has been double higher in relation to high-educated and secondary-educated women. On average for analysed age cohorts, $12.6 \%$ of low-educated women have lived in three or more-children families in compared to $6 \%$ of secondary-educated and $4.5 \%$ of high-educated women. On the other hand, the high prevalence of first-birth has been characteristic of high-educated woman. Almost double higher proportion of high-educated women have lived in one-child families in relation to less educated categories of women. Precisely, every the third higheducated woman has given to one child (30.5\%), in compared to $22.6 \%$ of secondaryeducated and $16.2 \%$ of low-educated women.

Graph 3: Distribution of women who gave birth by age, educational level and number of live born children in Serbia, 2011. (\%)

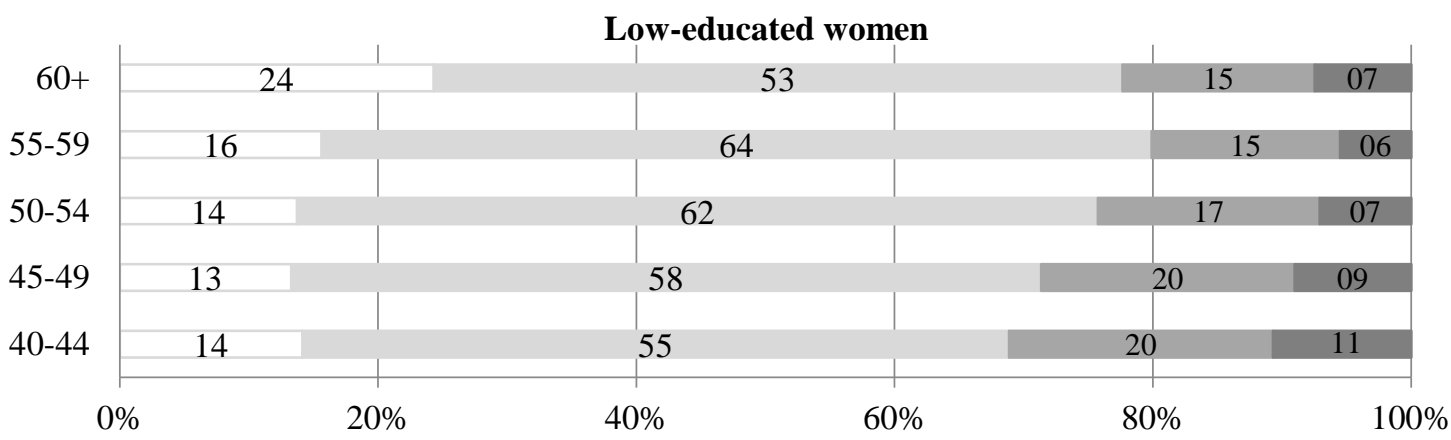

Secondary-educated women

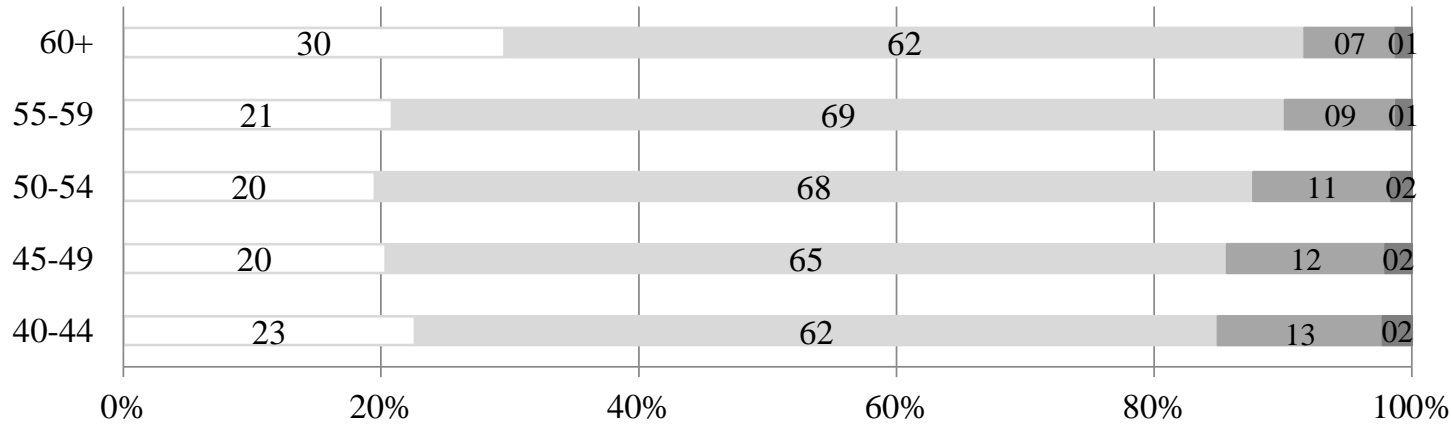

High-educated women

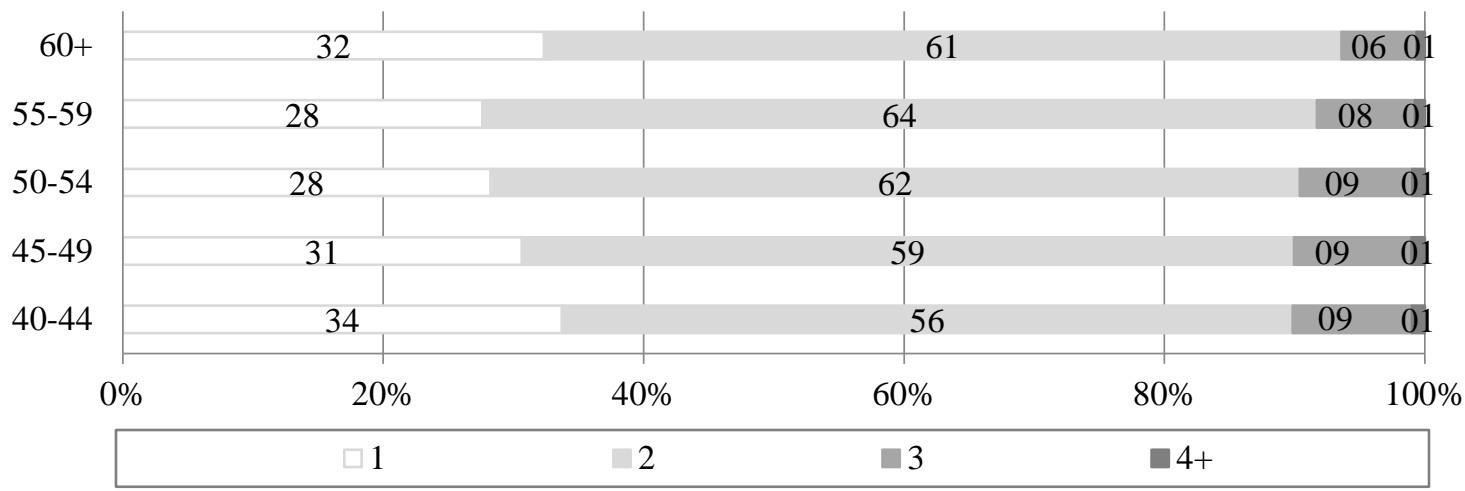

Source: Census of population and household 2011.

Comparison of age cohorts enables analysis of parity progression. Pattern of parity progression is different with regard to the women's educational level. The negative progression to first-birth and second-birth and positive progression to higher order of birth 
have been characteristic of low-educated and secondary-educated women. Pattern of parity progression among high-educated women has been implied a positive progression to first-birth and third-birth and negative progression to second-birth. Although the positive progression to higher order of birth (third and more) has been evident among all women regardless to their education, however, the share of women who have given birth to three or more children has been significantly lower among high-educated than less educated women in Serbia in all age cohorts.

\section{EDUCATIONAL PATTERN OF PROBABILITIES OF AN INCREASING OF FAMILY}

In general, the models of probabilities of an increasing of family have a similar shape "U" regardless of women's educational level. The probability of a woman with a one child to gives the second-birth (a1) has been lower than the probability of a woman without children to gives the first-birth (a0). Also, the probability of a woman with two children to gives the third-birth (a2) has been markedly lower than the probability of a woman with a one child to gives the second-birth (a1). The lowest value of the probabilities of an incresing of family is for women who have had two (a2) or three children (a3). Then, the probabilities of increasing of family for women with four and more children (a4 ...) have grown. Can be said that the duality of reproductive norms is characteristic of women in Serbia regardless of their education. However, keeping in mind that the absolute number of women who have had six and more children has been very small (Appendix), it can be concluded that women in Serbia have been characterized by the dominance of low reproductive norms.

Graph 4. The probabilities of an increasing of family for women above reproductive age (50+) by education level, Serbia, 2011.

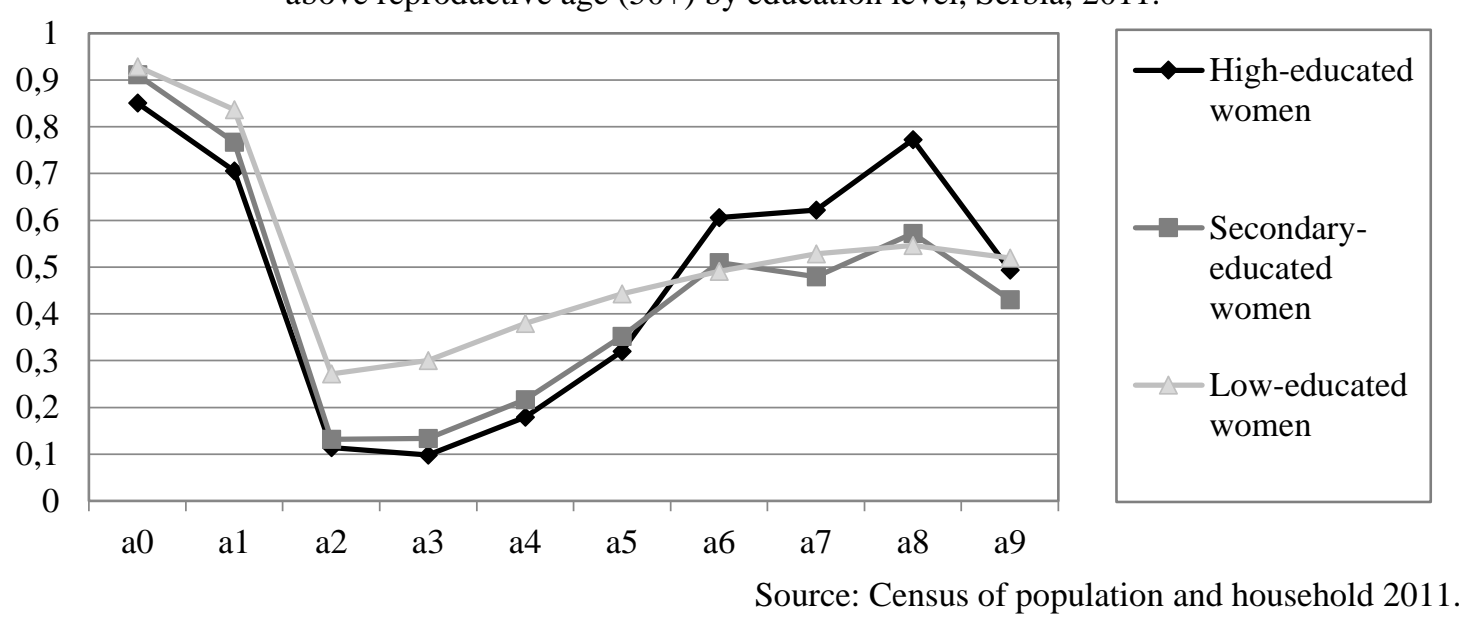

We can concluded that motherhood has an important in the life of women in Serbia regardless of their education. All analysed women have been characterized by a high probability to entering into parenthood (a0), as well as the probability to the second-birth (a1). Thus, "be a mother" has been highly valued by women of all levels of education in Serbia. However, the model of probabilities to higher order of birth shows an interesting pattern with regard to the women's educational level. The probabilities of woman to gives the third-birth (a2), the fourth-birth (a3), the fifth-birth (a4) and the sixth-birth (a5) have been triple higher among low-educated than high-educated women. Then, turn has been observed, i.e. the probabilities to the seventh-birth (a6), the eighth-birth (a7), the ninth- 
birth (a8) and the tenth-birth (a9) have been higher among high-educated than loweducated and secondary-educated women. Thus, the results indicate the duality of reproductive norms has been more pronounced among high-educated than less educated women. Nevertheless, it should be noted that the number of high-educated women who have lived in families with a large number of children are small (Appendix).

\section{CONCLUSION}

The analysis, based on the date from the Census 2011, has indicated the negative association between fertility and women's educational level in Serbia, i.e. an increasing of the share of high-educated women has been accompanied by declining of fertility. The fact is that the analysis has shown that motherhood is very important in the life of women of all educational levels. This has been confirmed by the value of the probabilities of entry into parenthood which are close to 1 for women of all education categories. „Achieve yourself as a mother" for majority of women means a two-children family which can be considered as a universal characteristic regardless of their education. However, reproductive behavior has differentiated with respect to the women's educational level. On the one hand, more frequent childlessness and one-child families is characteristic of high-educated women, and on the other hand, more frequent families with three or more children is characteristic of less educated women. In accordance to theoretical strongholds, socio-cultural explanation of these findings implies that the tertiary education leads to greater autonomy and individualization of women which is reflected in the non-acceptance of traditional norms according to which a woman is viewed solely as a mother. Motherhood - one of the ways of satisfaction of emotional needs among high-educated woman, but which does not necessarily mean "have a lots of kids". Economic explanation is that tertiary education implies, on the one hand, preferably invest in quality (eg. education) than the quantity of children, and on the other hand, the increasing of the cost (unpaid) of time that a woman "spent" on the childbearing. Explaining of these findings should be taken into consideration unfavorable socialeconomic context in Serbia. In the context of the economic theory of fertility, education is seen as an investment in human capital in which women invest a lot of time, effort and material resources. So, economic obstacles of parenthood have been most pronounced among high-educated women. The realization of their desires for a career and stability on the labor market which will provide more investment in the „quality“ of their children in the future, has been impeded in terms of the poor economic situation. This has been confirmed by finding about high level of childlessness among high-educated women who were in optimal reproductive age during the $90 \mathrm{~s}$ of $\mathrm{XX}$ century. This period was characterized by social, economic and political crisis which has affected on the reproductive behavior of women through a poor perception of the future.

\section{REFERENCES}

[1] Becker, G. \& Lewis, H. G. (1973). „On the Interaction between the Quantity and Quality of children“. Journal of Political Economy, Vol. 81, No. 2, pp. 279-288.

[2] Becker, G. (1991). A treatise of the Family. New York: Hardvard University Press

[3] Blagojević, M. (1997). Roditeljstvo i fertilitet. Beograd: Institut za sociološka istraživanja Filozofskog fakulteta. 
[4] Breznik, D. (1977). Demografija: analiza, metode i modeli. Beograd: Centar za demografska istraživanja.

[5] Gavrilović, A. (2006). Populaciona edukacija. Beograd: Društvo demografa Srbije.

[6] Government of the Republic of Serbia (2008). National childbirth rehabilitation strategy.

[7] Kravdal, Ø. \& Rindfuss, R. (2008). "Changing Relationships between Education and Fertility: A Study of Women and Men Born 1940 to 1964“. American Sociological Review, Vol. 73, No. 5, pp. 854-873.

[8] Lesthaeghe, R. \& Van de Kaa, D. (1986). Two demographic transitions. In: Population Growth and Decline (Eds. Lesthaeghe, R. and Van de Kaa, D.) (pp. 9-24), Deventer.

[9] Rašević, M. (2006). Fertilitet ženskog stanovništva. In: Stanovništvo u domaćinstva Srbije prema Popisu 2002. Godine (Eds. Penev, G.) (pp.53-70). Beograd: Statistical Office of the Serbia.

[10] Rašević, M. (2008). „Fenomen nedovoljnog rađanja i obrazovni sistem“. Zbornik radova Instituta za pedagoška istraživanja. Vol. 40. No. 1, pp. 192-206.

[11] Van de Kaa, D. (2001). „Postmodern Fertility Preference: From Changing Value Orientation to New Behavior". Population and Development Review, Vol. 27, pp. 290331.

[12] Vasić, P., Gligorijević, V. \& Devedžić, M. (2014). "Responding to population policy - which women can provide the greatest demographic benefit in Serbia?" Zbornik Matice Srpske za društvene nauke, Vol. 148, pp. 541-550.

\section{APPENDIX}

Age cohorts of women by educational level and number of live born children, 2011.

\begin{tabular}{|c|c|c|c|c|c|c|c|c|c|c|c|c|c|}
\hline \multirow{2}{*}{\begin{tabular}{|c|} 
Age \\
cohorts \\
of \\
women \\
\end{tabular}} & \multirow{2}{*}{$\begin{array}{c}\text { Women's } \\
\text { educational } \\
\text { level }\end{array}$} & \multirow{2}{*}{$\begin{array}{c}\text { Total } \\
\text { number } \\
\text { of } \\
\text { women }\end{array}$} & \multicolumn{11}{|c|}{ Women by number of live born children } \\
\hline & & & 0 & 1 & 2 & 3 & 4 & 5 & 6 & 7 & 8 & 9 & 10 \\
\hline \multirow{3}{*}{$40-44$} & & 47162 & 4035 & 6107 & 23591 & 8817 & 2899 & 944 & 371 & 171 & 110 & 55 & 62 \\
\hline & Seconda & 138372 & 15172 & 27906 & 76764 & 15777 & 2191 & 379 & 111 & 35 & 10 & 14 & 13 \\
\hline & & 49297 & 11092 & 12888 & 21438 & 3503 & 307 & 48 & 12 & 5 & 1 & 2 & 1 \\
\hline \multirow{3}{*}{$45-49$} & & 54242 & 4118 & 6648 & 29117 & 9828 & 2778 & 924 & 407 & 174 & 113 & 60 & 75 \\
\hline & Secon & 141801 & 12787 & 26271 & 84253 & 15834 & 2110 & 359 & 100 & 43 & 20 & 14 & 10 \\
\hline & & 48570 & 8807 & 121 & 23576 & 3601 & 330 & 51 & 8 & 6 & 1 & 4 & 1 \\
\hline \multirow{3}{*}{$50-54$} & & 80652 & 5402 & 10342 & 46655 & 12928 & 3336 & 1123 & 443 & 194 & 102 & 62 & 65 \\
\hline & Secon & 137289 & 10819 & 24685 & 86242 & 13517 & 1602 & 286 & 66 & 43 & 16 & 8 & 5 \\
\hline & & 46947 & 7140 & 11244 & 24735 & 3441 & 327 & 41 & 5 & 3 & 2 & 5 & 4 \\
\hline \multirow{3}{*}{$55-59$} & & 128372 & 7942 & 18 & 77396 & 17562 & 4202 & 1342 & 554 & 249 & 123 & 72 & 97 \\
\hline & Seconda & 131411 & 10673 & 25166 & 83688 & 10425 & 1151 & 194 & 56 & 31 & 10 & 8 & 9 \\
\hline & & & & & 25157 & 2950 & 246 & 42 & 7 & 6 & 1 & 1 & 3 \\
\hline \multirow{3}{*}{$60+$} & & 670916 & 56854 & 149284 & 327546 & 91221 & 27653 & 10187 & 4166 & 1986 & 998 & 538 & 483 \\
\hline & Seconda & 227112 & 24152 & 60061 & 126020 & 14404 & 1905 & 365 & 103 & 44 & 21 & 23 & 14 \\
\hline & ig & 97941 & 14894 & 26862 & 50875 & 4782 & 429 & 65 & 18 & 6 & 3 & 5 & 2 \\
\hline
\end{tabular}

